2 Ballast water exchange plus treatment lowers species

5 Johanna N. Bradie ${ }^{1,2}$, D. Andrew R. Drake ${ }^{1}$, Dawson Ogilvie ${ }^{1}$, Oscar Casas-Monroy ${ }^{1}$, and Sarah

$8{ }^{1}$ Great Lakes Laboratory for Fisheries and Aquatic Sciences, Fisheries and Oceans Canada, 867

$10 \quad{ }^{2}$ Current address: Great Lakes Institute for Environmental Research, University of Windsor, 401

13 Number of pages: 12

14 Number of tables: 4

15 Number of figures: 7 
16 Table S1. Sample size of voyages $(n=2,980)$ for each salinity combination within a given

17 shipping pathway. Sample year indicates the timespan for which transit data were available for

18 each region.

\begin{tabular}{cccccccc}
$\begin{array}{c}\text { Recipient } \\
\text { Port } \\
\text { Salinity }\end{array}$ & $\begin{array}{c}\text { Source Port } \\
\text { Salinity }\end{array}$ & $\begin{array}{c}\text { All Shipping } \\
\text { Pathways }\end{array}$ & $\begin{array}{c}\text { Great Lakes- } \\
\text { St. Lawrence } \\
\text { River } \\
\text { International }\end{array}$ & $\begin{array}{c}\text { Pacific } \\
\text { International }\end{array}$ & $\begin{array}{c}\text { Atlantic } \\
\text { International }\end{array}$ & $\begin{array}{c}\text { Arctic } \\
\text { International }\end{array}$ & $\begin{array}{c}\text { Arctic } \\
\text { Domestic }\end{array}$ \\
\hline Fresh & Fresh & 87 & 67 & 9 & 11 & 0 & 0 \\
& Brackish & 77 & 58 & 17 & 2 & 0 & 0 \\
& Marine & 324 & 186 & 136 & 2 & 0 & 0 \\
\hline \multirow{2}{*}{ Brackish } & Fresh & 27 & 0 & 0 & 27 & 0 & 0 \\
& Brackish & 40 & 0 & 1 & 39 & 0 & 0 \\
\hline \multirow{3}{*}{ Marine } & Marine & 59 & 0 & 26 & 33 & 0 & 0 \\
& Bresh & 458 & 0 & 105 & 329 & 4 & 20 \\
& Mrackish & 638 & 0 & 153 & 478 & 7 & 0 \\
\hline & & 1,270 & 0 & 940 & 307 & 18 & 5 \\
\hline
\end{tabular}

19

20 
21 Table S2. Number of empirical ballast water samples available with estimates of zooplankton

22 abundance and species richness for each shipping pathway. Note that due to limited biological

23 data, the Arctic domestic pathway used zooplankton data from ships arriving to the Arctic from

24 Atlantic Canada, and from internal Great Lakes-St. Lawrence River transits.

\begin{tabular}{cc} 
Shipping Pathway & Number of Samples \\
\hline Pacific International & 50 \\
Atlantic International & 39 \\
Great Lakes-St. Lawrence River International & 19 \\
Arctic International & 31 \\
Arctic Domestic & 74
\end{tabular}

25

26 
27 Table S3. Model parameters used to estimate the mean number of nonindigenous zooplankton

28 species establishing in Canadian ecosystems.

\begin{tabular}{|c|c|c|c|c|c|c|c|}
\hline \multirow{3}{*}{$\begin{array}{c}\text { Model } \\
\text { Paramete }\end{array}$} & & \multicolumn{6}{|c|}{ Shipping Pathway } \\
\hline & & \multirow{2}{*}{$\begin{array}{l}\text { Great Lakes-St. } \\
\text { Lawrence River } \\
\text { International }\end{array}$} & \multirow[b]{2}{*}{ Pacific International } & \multirow[b]{2}{*}{ Atlantic International } & \multirow[b]{2}{*}{ Arctic International } & \multicolumn{2}{|c|}{ Arctic Domestic* } \\
\hline & & & & & & Atlantic & GLSLR \\
\hline $\begin{array}{l}\text { Sample } \\
\text { Concentration } \\
\text { (Negative }\end{array}$ & size & 0.6297 & 0.2783 & 0.8268 & 0.2894 & 1.5618 & 0.4034 \\
\hline $\begin{array}{l}\text { Binomial } \\
\text { Distribution) }\end{array}$ & $\mu$ & 752.00 & 8861.66 & 13099.23 & 1661.77 & 77349.90 & 123550.70 \\
\hline \multicolumn{2}{|c|}{$\begin{array}{l}\text { Population Concentration } \\
\text { Error }\end{array}$} & \multicolumn{6}{|c|}{ Poisson } \\
\hline \multirow{2}{*}{$\begin{array}{l}\text { Proportion } \\
\text { Nonindigenous } \\
\text { (Beta) }\end{array}$} & $\alpha$ & 0.7515 & 0.2302 & 0.1842 & 0.0973 & 1.0696 & 0.2411 \\
\hline & $\beta$ & 0.4004 & 2.9896 & 14.1509 & 0.4625 & 7.9209 & 1.1468 \\
\hline
\end{tabular}

\section{All Trips}

Probability

Single Propagule

Establishes

(Beta)

0.005

Allee Effect

$\alpha$

$\beta$

5

$c$

1

*The Arctic domestic pathway used zooplankton data from ships arriving to the Arctic from Atlantic Canada, and from internal Great LakesSt. Lawrence River transits. 
Table S4. Sensitivity analysis results.

\begin{tabular}{|c|c|c|c|c|c|c|c|c|c|c|}
\hline \multirow{2}{*}{$\begin{array}{l}\text { Management } \\
\text { Scenario }\end{array}$} & \multirow[b]{2}{*}{ Null } & \multirow{2}{*}{$\begin{array}{l}\text { Randomized } \\
\text { Port Pairings }\end{array}$} & \multicolumn{2}{|c|}{$\begin{array}{c}\text { Transit } \\
\text { Frequency }\end{array}$} & \multicolumn{2}{|c|}{$\begin{array}{c}\text { Mean Plankton } \\
\text { Concentration } \\
\mu\end{array}$} & \multicolumn{2}{|c|}{$\begin{array}{c}\text { Mean } \\
\text { Nonindigenous } \\
\beta\end{array}$} & \multirow{2}{*}{$\begin{array}{c}\alpha=0.005 \\
\text { All } \\
\text { Species }\end{array}$} & \multirow{2}{*}{$\begin{array}{l}\text { Allee } \\
\text { Effect } \\
c=2\end{array}$} \\
\hline & & & $+25 \%$ & $-25 \%$ & $+25 \%$ & $-25 \%$ & $+25 \%$ & $-25 \%$ & & \\
\hline NM & 1.85 & 1.86 & 2.00 & 1.76 & 2.13 & 1.73 & 2.03 & 1.76 & 54.63 & 3.98 \\
\hline E & 1.87 & 1.89 & 1.99 & 1.74 & 2.13 & 1.72 & 2.02 & 1.70 & 54.32 & 3.92 \\
\hline $\mathrm{T}(\mathrm{PE})$ & 0.80 & 0.81 & 0.89 & 0.73 & 0.86 & 0.78 & 0.87 & 0.74 & 22.29 & 1.78 \\
\hline $\mathrm{E}+\mathrm{T}(\mathrm{PE})$ & 0.75 & 0.77 & 0.81 & 0.71 & 0.82 & 0.79 & 0.83 & 0.68 & 20.83 & 1.69 \\
\hline $\mathrm{T}(\mathrm{FE})$ & 0.06 & 0.06 & 0.07 & 0.06 & 0.07 & 0.07 & 0.08 & 0.05 & 0.48 & 0.05 \\
\hline $\mathrm{E}+\mathrm{T}(\mathrm{FE})$ & 0.05 & 0.06 & 0.06 & 0.06 & 0.06 & 0.07 & 0.07 & 0.03 & 0.35 & 0.03 \\
\hline
\end{tabular}

The response variable is the mean number of species per year among all Canadian ports (fresh, brackish, and marine) examined in this study. The management methods assessed are no management (NM), exchange only (E), treatment only (T), and exchange plus treatment $(\mathrm{E}+\mathrm{T})$. Ballast water treatment systems were either partially effective on half of the transits (PE) or fully effective on all transits (FE). An outcome with less or greater than 1:1 response indicates the model is insensitive or very sensitive to changes to a parameter. Outcomes with large deviations ( $>25 \%$ change) relative to the null are in bold. 
32 Figure S1. The Canadian geographical regions with the shipping ports examined in this study.

33 The four Canadian regions of interest are the Pacific, Atlantic, Great Lakes-St. Lawrence River

34 (GLSLR), and Arctic. The Great Lakes-St. Lawrence River region includes all freshwater ports

35 upstream of and including Québec City. The destination ports $(n=72)$ included in this study are

36 displayed by the markers where their color and size represent their salinity category and number

37 of arrivals, respectively.

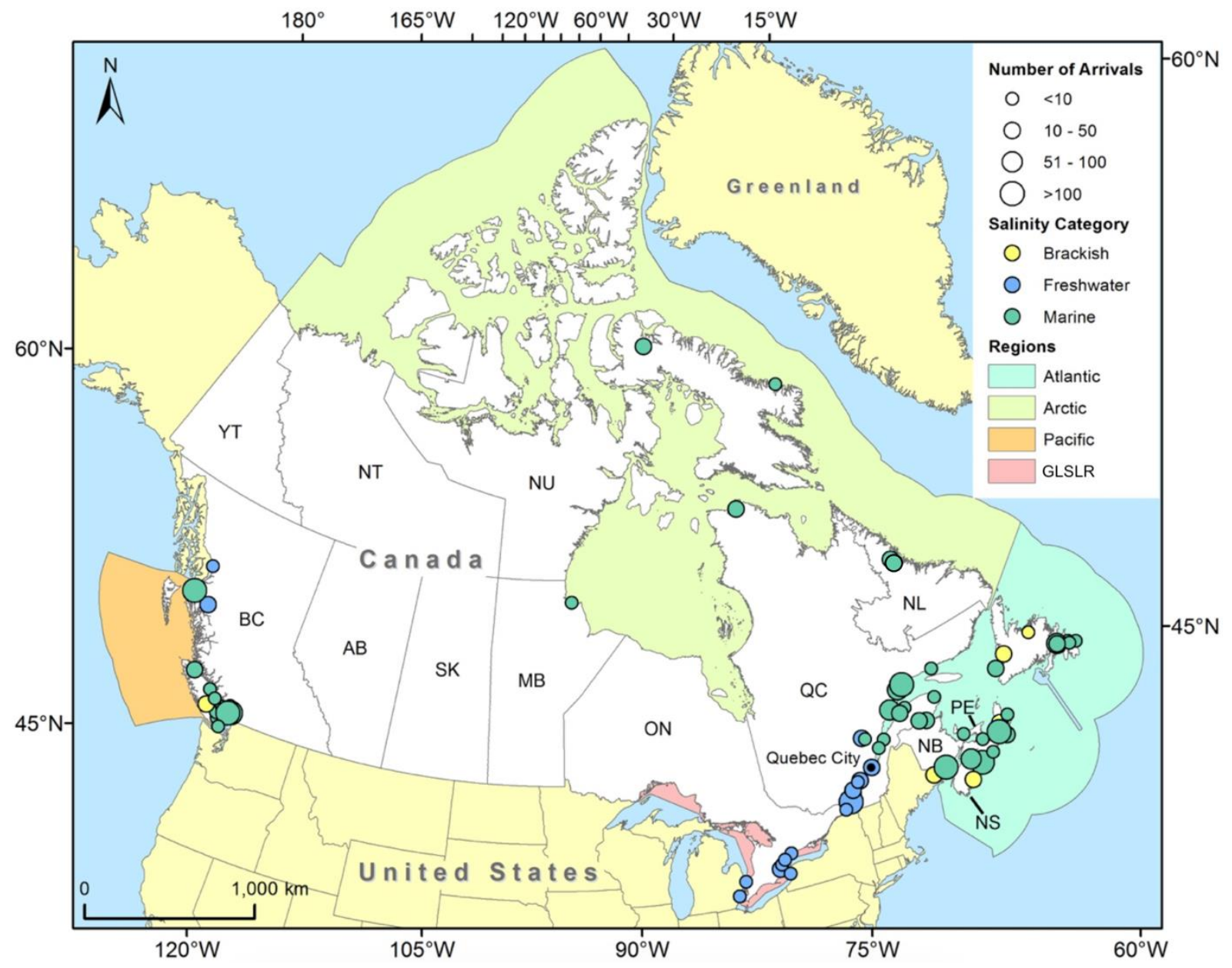


40 Figure S2. Probability distribution describing the zooplankton sample concentration (individuals

41 per $\mathrm{m}^{3}$ ) among ship transits within each shipping pathway. The Arctic domestic pathway used

42 zooplankton data from ships arriving to the Arctic from Atlantic Canada (bottom right panel),

43 and from internal Great Lakes-St. Lawrence River (GLSLR) transits (bottom left panel). The

44 black lines represent the probability density function.

Pacific International

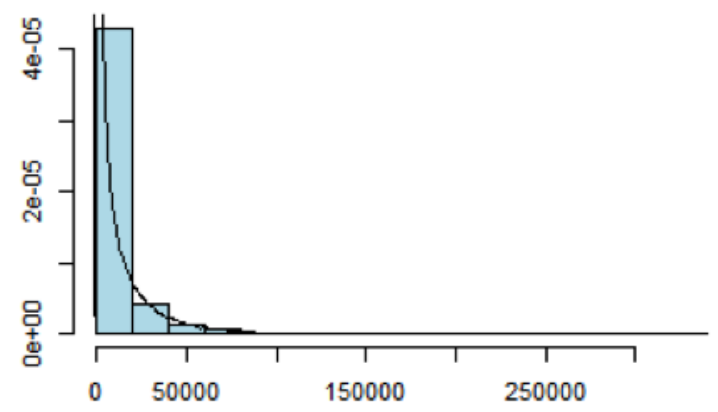

GLSLR International

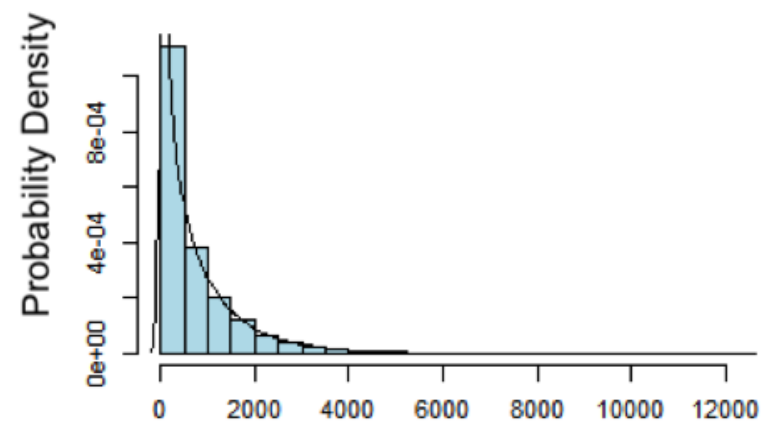

Arctic Domestic: GLSLR Source

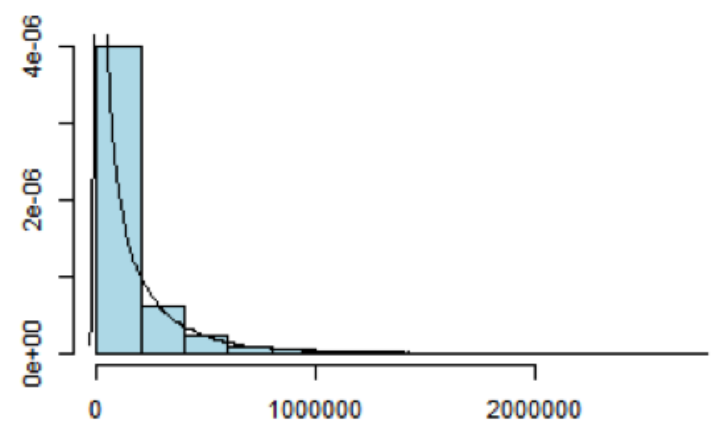

Atlantic International
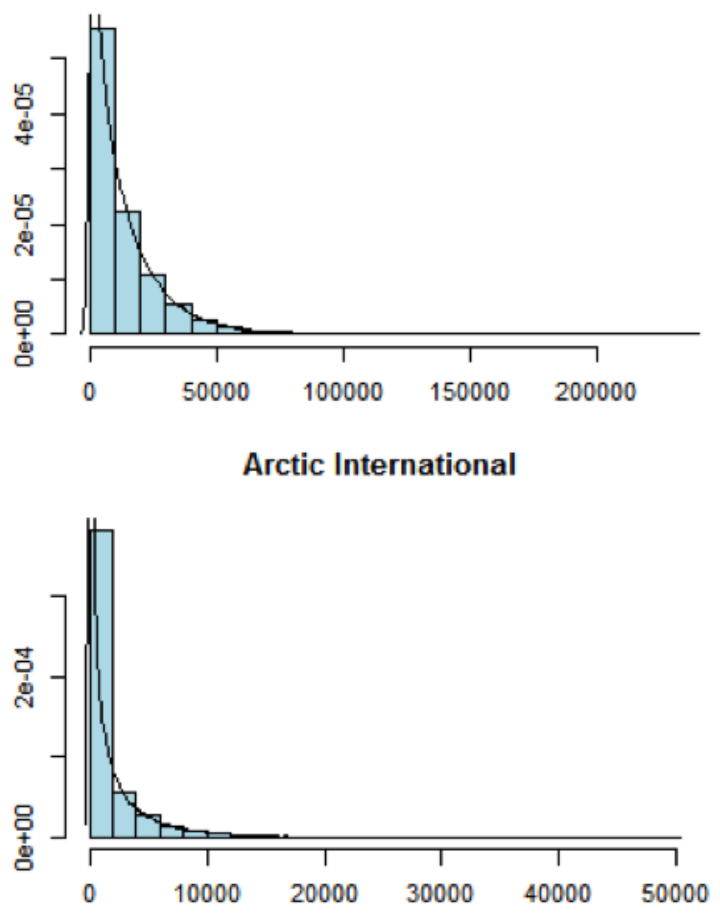

Arctic Domestic: Atlantic Source

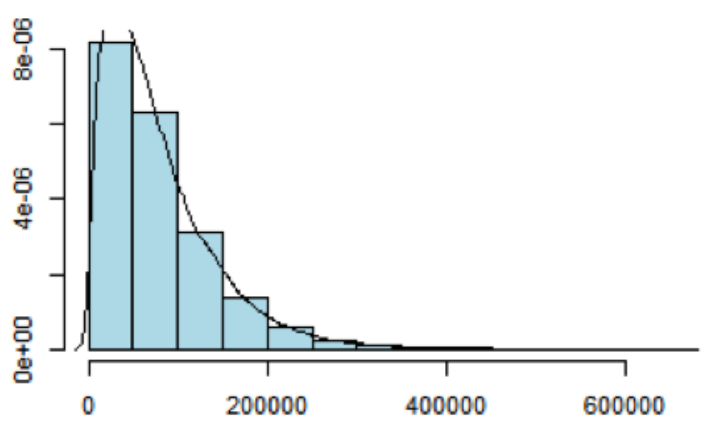


46 Figure S3. An example $C_{p} \mid C_{s}$ distribution describing the population concentration of

47 zooplankton in a single ship, with a sample concentration of 10,000 zooplankton per $\mathrm{m}^{3}$.

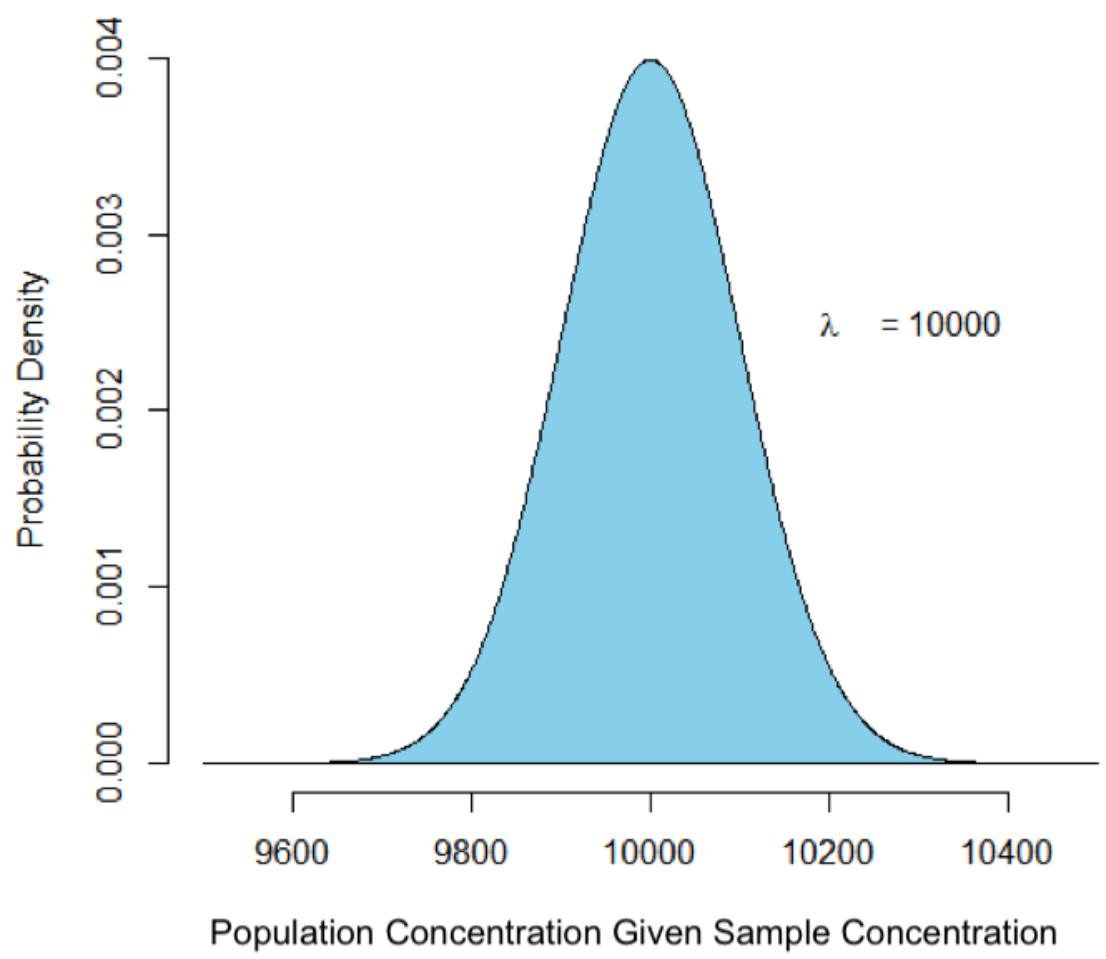

48

49 
50 Figure S4. Probability distributions describing the proportion of nonindigenous zooplankton out

51 of the total organism concentration among ship trips within each shipping pathway. The Arctic

52 domestic pathway used zooplankton data from ships arriving to the Arctic from Atlantic Canada

53 (bottom right panel), and from internal Great Lakes-St. Lawrence River (GLSLR) transits

54 (bottom left panel). The black lines represent the probability density function.

Pacific International
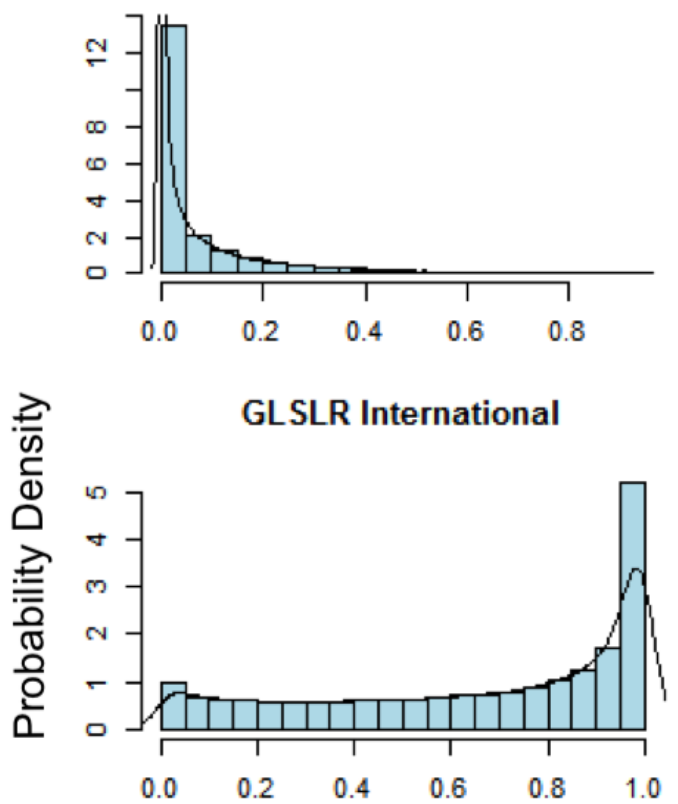

Arctic Domestic: GLSLR Source

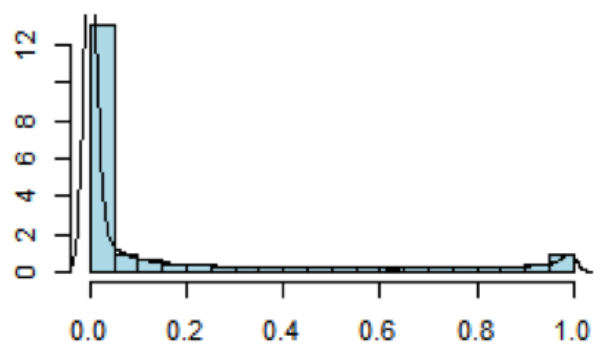

Atlantic International

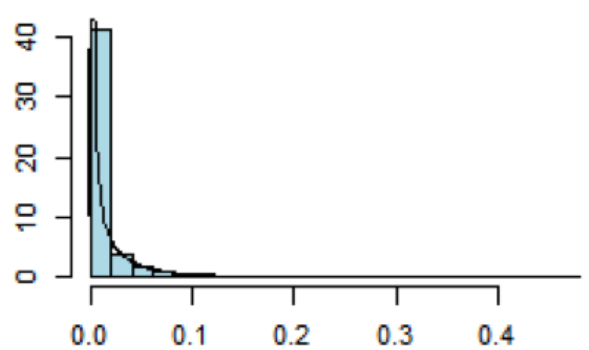

Arctic International

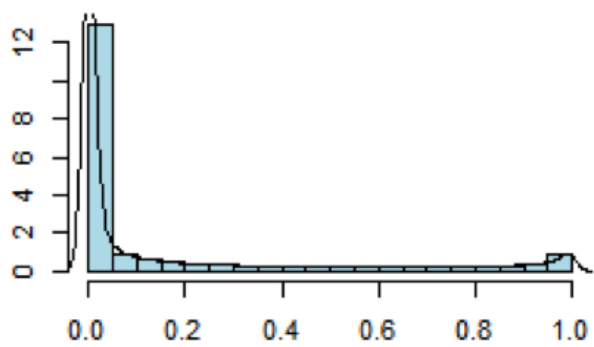

Arctic Domestic: Atlantic Source

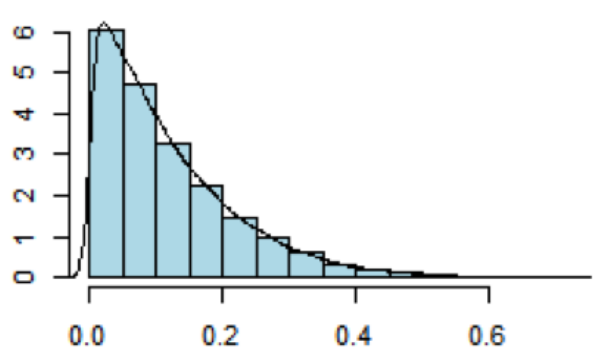


56 Figure S5. Environmental distance curve. $\mathrm{P}(\mathrm{Y}=1)$ represents the probability of survival in the 57 recipient environment given the temperature match between the source and recipient 58 environments.

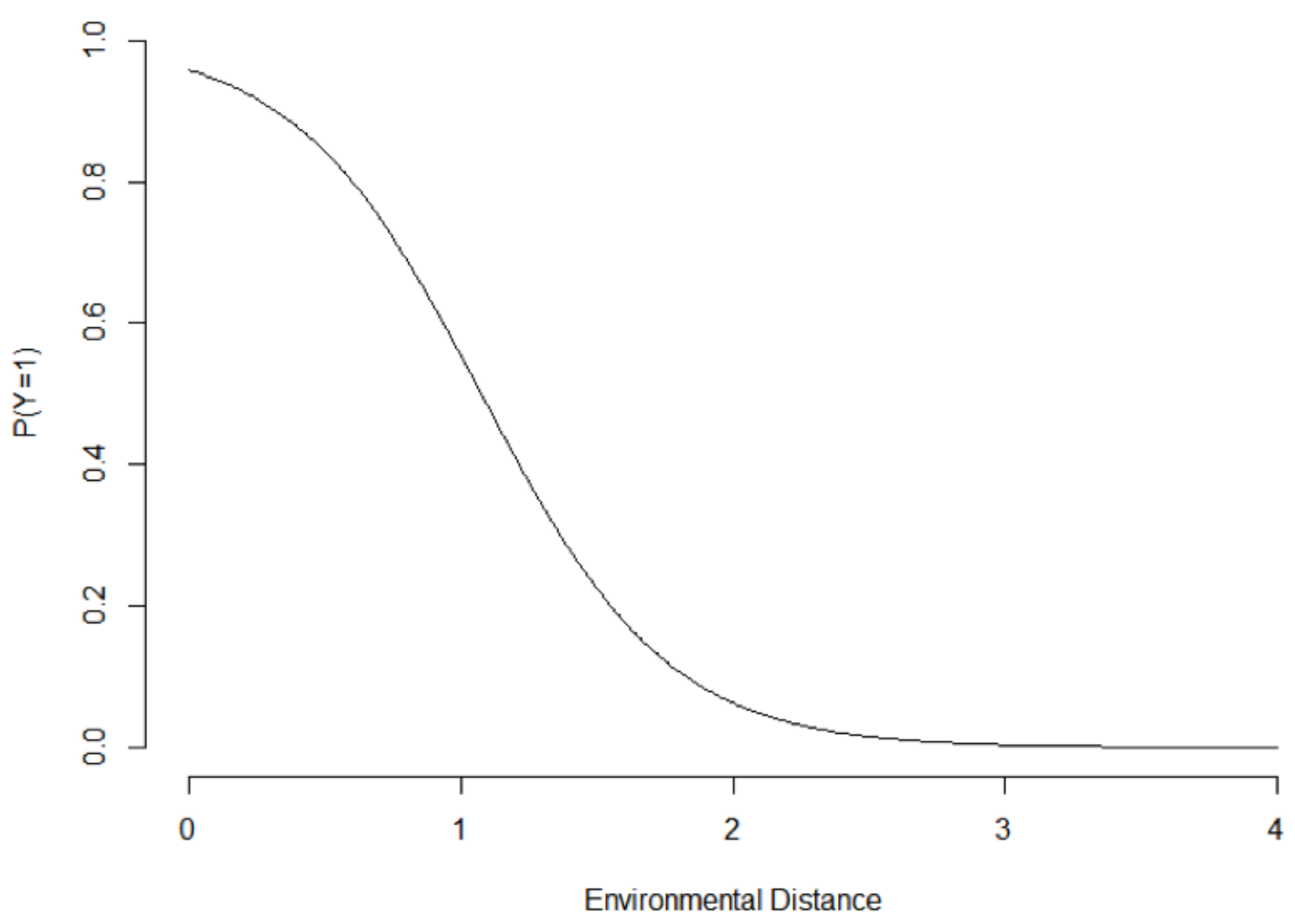

59

60 
61 Figure S6. Examples of the probability of establishment based on the per-capita probability of

62 establishment $(\alpha)$, initial organism concentration (individuals per $\mathrm{m}^{3}$ ), and Allee effect $(c)$.

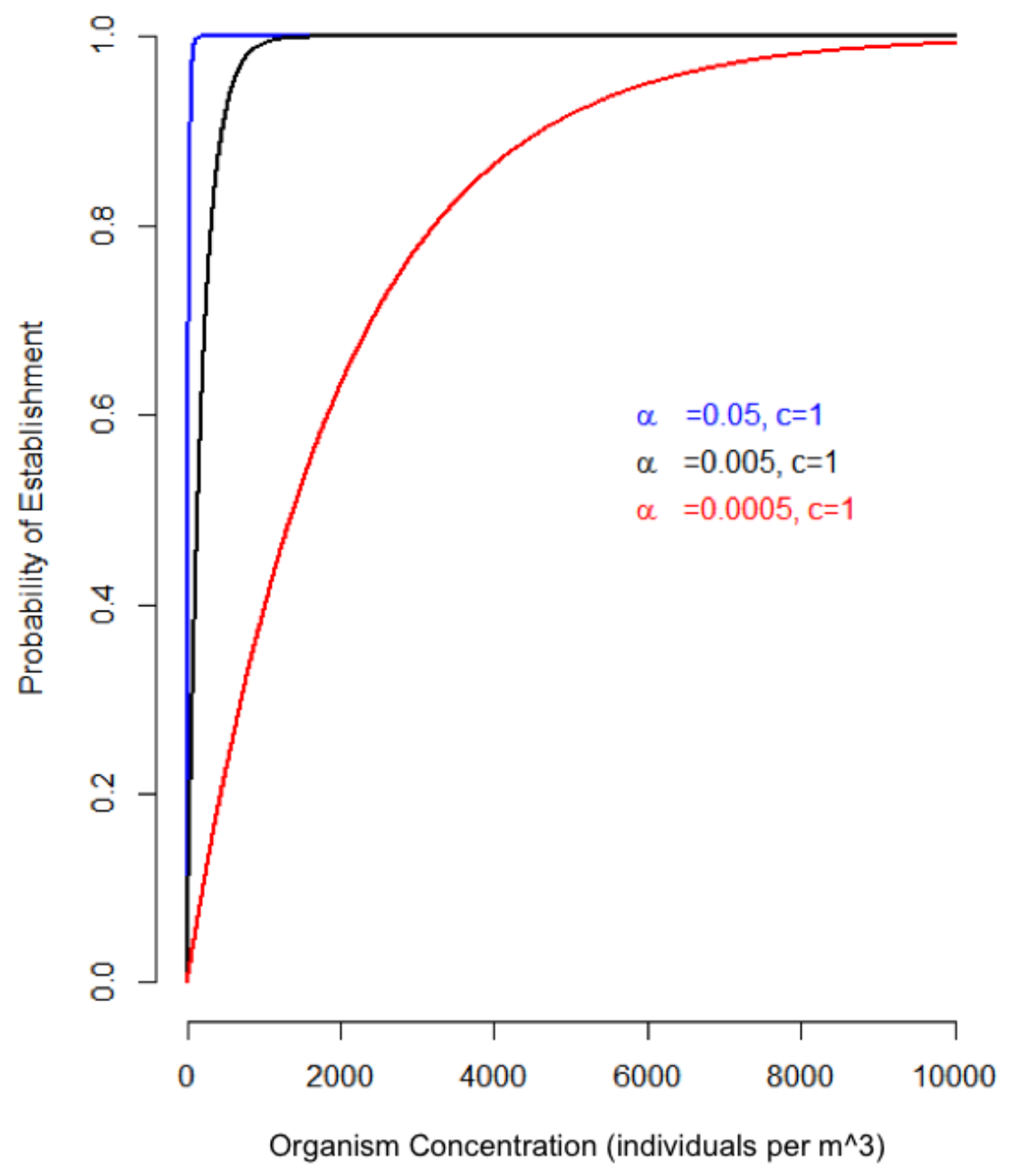

63

64 
65 Figure S7. Probability distribution describing the per-capita probability of establishment $(\alpha)$

66 across multiple species in a ballast tank. This distribution was identical across all trips and

67 shipping pathways.

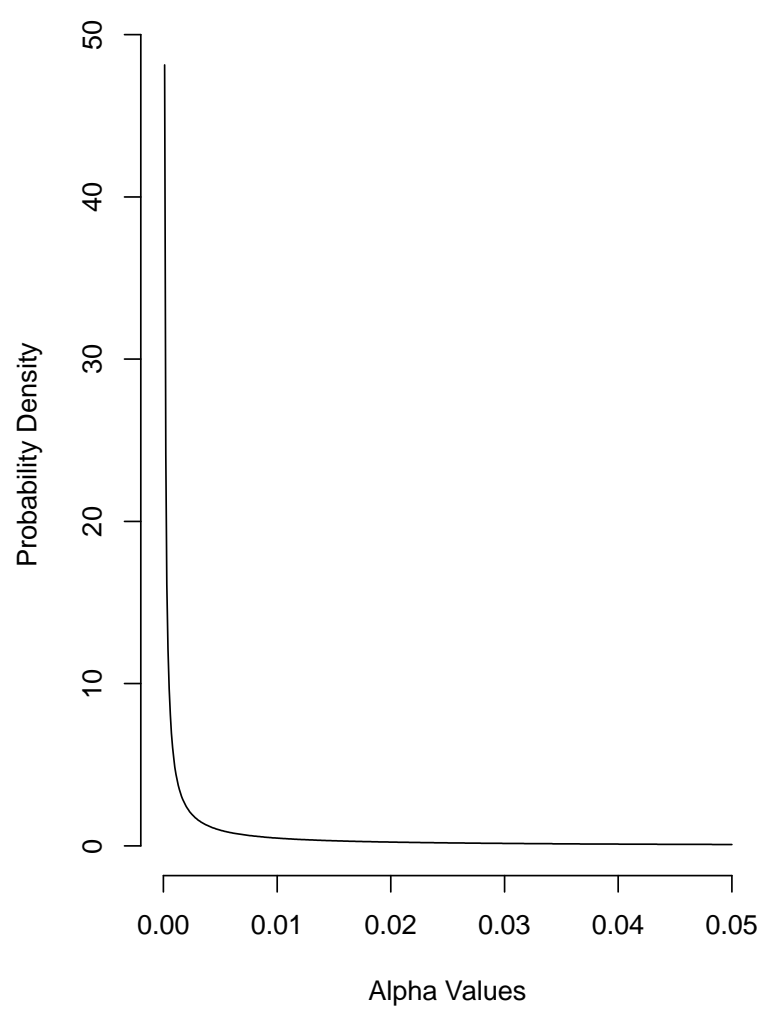

